\title{
Optical, microphysical and compositional properties of the Eyjafjallajökull volcanic ash
}

\author{
A. Rocha-Lima ${ }^{1}$, J. V. Martins ${ }^{1,2}$, L. A. Remer ${ }^{1}$, N. A. Krotkov ${ }^{2}$, M. H. Tabacniks ${ }^{3}$, Y. Ben-Ami ${ }^{4}$, and P. Artaxo ${ }^{3}$ \\ ${ }^{1}$ University of Maryland, Baltimore County, Baltimore, MD, USA \\ ${ }^{2}$ NASA Goddard Space Flight Center, Greenbelt, MD, USA \\ ${ }^{3}$ Institute of Physics, University of Sao Paulo, Sao Paulo, Brazil \\ ${ }^{4}$ Weizmann Institute of Science, Rehovot, Israel
}

Correspondence to: A. Rocha-Lima (limadri1@ umbc.edu)

Received: 28 February 2014 - Published in Atmos. Chem. Phys. Discuss.: 22 May 2014

Revised: 11 August 2014 - Accepted: 30 August 2014 - Published: 10 October 2014

\begin{abstract}
Better characterization of the optical properties of aerosol particles are an essential step to improve atmospheric models and satellite remote sensing, reduce uncertainties in predicting particulate transport, and estimate aerosol forcing and climate change. Even natural aerosols such as mineral dust or particles from volcanic eruptions require better characterization in order to define the background conditions from which anthropogenic perturbations emerge. We present a detailed laboratorial study where the spectral optical properties of the ash from the April-May (2010) Eyjafjallajökull volcanic eruption were derived over a broad spectral range, from ultra-violet (UV) to near-infrared (NIR) wavelengths. Samples of the volcanic ash taken on the ground in the vicinity of the volcano were sieved, re-suspended, and collected on filters to separate particle sizes into fine and mixed (coarse and fine) modes. We derived the spectral mass absorption efficiency $\alpha_{\mathrm{abs}}\left[\mathrm{m}^{2} \mathrm{~g}^{-1}\right]$ for fine and mixed modes particles in the wavelength range from 300 to $2500 \mathrm{~nm}$ from measurements of optical reflectance. We retrieved the imaginary part of the complex refractive index $\operatorname{Im}(m)$ from $\alpha_{\mathrm{abs}}$, using MieLorenz and T-matrix theories and considering the size distribution of particles obtained by scanning electron microscopy (SEM), and the grain density of the volcanic ash measured as $\rho=2.16 \pm 0.13 \mathrm{~g} \mathrm{~cm}^{-3} . \operatorname{Im}(m)$ was found to vary from 0.001 to 0.005 in the measured wavelength range. The dependence of the retrieval on the shape considered for the particles were found to be small and within the uncertainties estimated in our calculation. Fine and mixed modes were also analyzed by X-ray fluorescence, exhibiting distinct elemental composition supporting the optical differences we found between the modes. This is a comprehensive and consistent character-
\end{abstract}

ization of spectral absorption and imaginary refractive index, density, size, shape and elemental composition of volcanic ash, which will help constrain assumptions of ash particles in models and remote sensing, thereby narrowing uncertainties in representing these particles both for short-term regional forecasts and long-term climate change.

\section{Introduction}

Aerosols, small liquid or solid particles suspended in the atmosphere, are important atmospheric constituents that affect Earth's energy balance, clouds, weather, climate, visibility, aircraft safety and air quality (Chin et al., 2009; Twomey, 1977; Boucher et al., 2013; Malm et al., 2004; Casadevall, 1994; Lim et al., 2012). Atmospheric models that represent any of these phenomena, processes or consequences, and remote sensing algorithms that intend to return quantitative information about the Earth system require assumptions of these particles' microphysical, optical and compositional properties (Chin et al., 2009). Specifically, to properly represent aerosols in a model or algorithm, we require spectral real and imaginary refractive indices, shape and size distribution (or scattering phase matrix), density and composition (Lenoble et al., 2013). These properties define how the particles absorb and scatter light (Bond et al., 2006), how they may heat or cool the atmosphere (Jacobson, 2001; Ramanathan and Carmichael, 2008), affect cloud formation and processes (Lohmann and $\mathrm{Fe}$ ichter, 2005; Andreae and Rosenfeld, 2008), undergo chemical transformation (Andreae and Crutzen, 1997), and perturb 
climate (Hansen et al., 1997; Yu et al., 2006). These properties also enable the estimation of aerosol mass used in atmospheric models from measures of aerosol optical depth, commonly observed by remote sensing systems (Schulz et al., 2006; Hand and Malm, 2007).

Although these properties are of fundamental importance for a wide range of atmospheric applications, there is still a lack of data available for different aerosol types. Much of the aerosol community relies on retrievals of aerosol properties from ground-based remote sensing, e.g., Dubovik et al. (2002) with over 1000 citations. The advantage of these data is that they represent the optical properties of the total column ambient aerosol. However, these retrievals are subject to their own assumptions and limitations. For example, the retrievals are made for only four wavelengths in the range of 440 to $870 \mathrm{~nm}$ and a uniform refractive index is assumed for all size modes (Dubovik and King, 2000). In addition, the retrieval requires sky homogeneity and moderately high aerosol loading, and cannot isolate specific aerosol layers in the column.

Direct measurements of optical properties can be made in the field (Hunton et al., 2005) or can be applied to aerosol samples that are brought back to the laboratory (Pollack et al., 1973; Patterson et al., 1983; Volten et al., 2001; Kirchstetter et al., 2004). There are many aerosol property measurements in the literature, but few offer a consistent and comprehensive array of properties that allow full characterization of the particles' mass, size, shape, refractive index and composition. For example, in situ measurements of aerosols in volcanic ash plumes over Europe yielded ash mass concentrations only after values for density and refractive indices were inferred from elemental composition, not direct measurements (Schumann et al., 2011).

Volcanic eruptions are an important source of aerosols to the atmosphere. Because eruptions are sporadic, they introduce high variability to the total global aerosol burden (Chin et al., 2014). Estimates of anthropogenic forcing and humaninduced climate change require characterization of background conditions (Bellouin et al., 2008). Volcanic aerosols in particular make it difficult to characterize the baseline from which to estimate the anthropogenic perturbation to the natural system (Yuan et al., 2012; Chin et al., 2014). In addition, volcanic ash creates significant concerns for aircraft safety (Casadevall, 1994).

In April 2010, after almost 200 years from its last eruption in 1821-1823, the Eyjafjallajökull volcano on the southern edge of Iceland initiated seismic activity. Although the eruption is considered to be of small to moderate size, the volcanic ash injected into the atmosphere spread over much of Europe due to fine particle fragmentation during magma-ice interaction and weather conditions that facilitated the rapid transport of the plume toward European airspace. The spread caused an unprecedented interruption of the aircraft traffic in Europe with important economic and social impacts (Gudmundsson et al., 2010; Langmann et al., 2012).
During the April-May (2010) Eyjafjallajökull volcanic eruption, the scientific community combined information from ground, aircraft (Schumann et al., 2011; Newman et al., 2012; Rauthe-Schöch et al., 2012) and remote sensing (Ansmann et al., 2010; Gasteiger et al., 2011) to evaluate the actual conditions and to recommend air traffic restrictions. These recommendations were based mainly on transport model assessments, supported by optical measurements including lidar observations that had to be converted to mass. To obtain mass from the observations, microphysical properties of the volcanic ash had to be assumed (Newman et al., 2012). The mass absorption, scattering and extinction efficiencies $\left[\mathrm{m}^{2} \mathrm{~g}^{-1}\right]$ are the main quantities connecting the optical properties and the bulk mass of the aerosol particles. Current assumptions on the optical and microphysical properties of aerosols are based on limited classical studies now 30 years old (Patterson et al., 1981, 1983). Because the classical studies are limited to a single visible wavelength, the spectral dependence of the refractive index, particularly the imaginary part, is usually unknown for most aerosol particles, including volcanic ash. Also, seldom are the classical measures of refractive index combined consistently with measures of size distribution, shape and composition in a way that provides strong constraints on the scattering and absorption properties of the ash. The uncertainty in the refractive index and the assumptions in the particle shape and internal mixtures are the main sources of error in the retrieval of optical depths (Ilyinskaya et al., 2011; Krotkov et al., 1998; Yi et al., 2011).

The main objective of this study is to help fill the gaps in knowledge that would allow observations to better constrain model representations of the Eyjafjallajökull volcanic ash for future regional transport predictions and ultimately to be applied to possible climate applications. To do so we present measured spectral optical properties of the ash, derived over a broad spectral range, from ultra-violet (UV) to near-infrared (NIR) wavelengths.

The sample of the Eyjafjallajökull volcanic ash collected on the ground was initially sieved, resuspended and re-collected on filters. Several analytical techniques were used to characterize the ash samples. Scanning electron microscopy (SEM) data were used to get the shape and size distribution. X-ray fluorescence (XRF) was used to obtain the chemical composition of the volcanic ash. The density of the grain was measured independently using a densimetry method, and optical reflectance analyses were used to derive the mass absorption efficiency.

The imaginary part of the complex refractive index $\operatorname{Im}(m)$ was calculated through an iterative inversion process. This calculation was obtained by combining the empirical power law method and the size distribution method, as will be described in the following sections. Both the Mie-Lorenz theory and the T-Matrix code (Mishchenko et al., 1996) were applied for the determination of the refractive index with the 


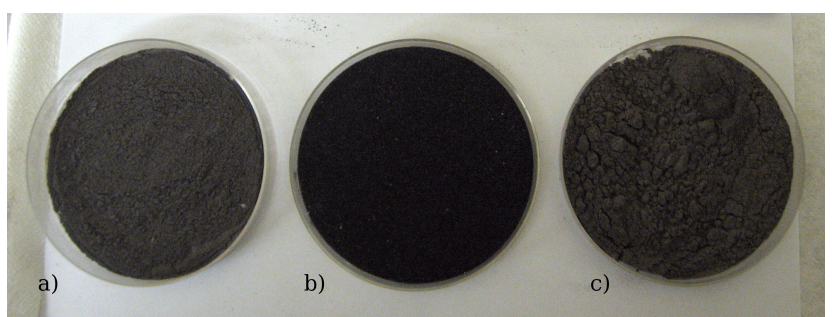

Figure 1. Samples of volcanic ash from the April-May (2010) Eyjafjallajökull volcanic eruption. (a) Original sample collected from the ground. (b) Fraction removed by sieving process (particles larger than $45 \mu \mathrm{m}$ ). (c) Fraction re-suspended for analysis (particles smaller than $45 \mu \mathrm{m})$.

assumption of spherical and spheroid particle shape respectively.

\section{Experimental methods and analyses}

\subsection{Volcanic ash resuspension and filter collection}

The volcanic ash sample studied in this research was collected on the ground about $35 \mathrm{~km}$ from the volcano Eyjafjallajökull at the village of $\operatorname{Vik}\left(63.42^{\circ} \mathrm{N}, 10.01^{\circ} \mathrm{W}\right)$ on 8 May 2010, 4 weeks after the first volcanic eruption. The sample was shoveled into a small bag from the ground.

At the Laboratory for Aerosols and Clouds Optics (LACO) at the University of Maryland, Baltimore County (UMBC), the material was initially sieved to retain particles smaller than $45 \mu \mathrm{m}$. This sieving is done by gently shaking the sieve. Any fragmentation or abrasion of the volcanic ash is unlikely in this process given the high hardness of this material (Gislason et al., 2011). Particles larger than $45 \mu \mathrm{m}$ were discarded and not analyzed due to their short residence time in the atmosphere. Figure 1 shows (a) the original sample, as it was collected on the ground, (b) the discarded fraction with particles larger than $45 \mu \mathrm{m}$ and (c) the fraction below $45 \mu \mathrm{m}$ retained to be re-suspended. We found that approximately $1 / 3$ of the mass of the original material collected on the ground was formed by particles smaller than $45 \mu \mathrm{m}$.

Sieved particles (c) smaller than $45 \mu \mathrm{m}$ were submitted to a re-suspension procedure in a fluidized bed aerosol generator (FBAG), TSI model 3400A, where they were disaggregated down to submicron sizes and carried out by a flow of dry air (Fig. 2). In this process, agglomerates generally formed by small particles attached to larger particles are able to be separated without damaging the individual particles. This process is important because samples of particles deposited on the ground commonly show small particles statically attached to large particles. The disaggregation/separation of these agglomerates in the FBAG produces a more realistic particle size distribution. In addition, the sin-

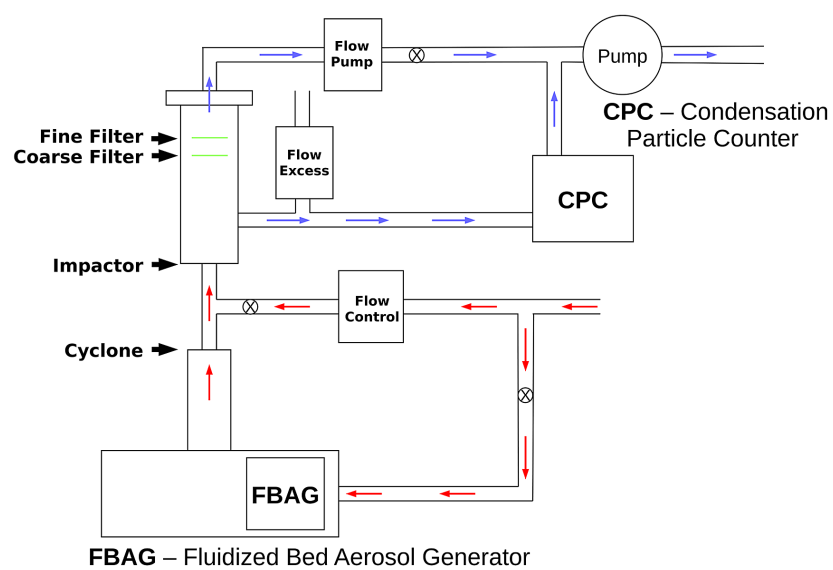

Figure 2. Sketch of experimental set-up showing the Fluidized Bed Aerosol Generator (FBAG) at the bottom with air flow lines for aerosol re-suspension.

gle light-particle interaction theories (Mie and T-matrix) that were applied in our analysis assume this condition.

A cyclone and an impactor at the exit nozzle of the FBAG were used to remove particles larger than $10 \mu \mathrm{m}$. A condensation particle counter, TSI model 3772 , was used to monitor the concentration of particles generated by the FBAG. Omega flow meters, model FMA, were used to monitor the air flow in the different lines of our set-up. Nuclepore ${ }^{\circledR}$ filters with pores of $5 \mu \mathrm{m}$ (coarse filter) and $0.4 \mu \mathrm{m}$ (fine filter) in diameter were used to separate the sample into different size modes. The Nuclepore filters work like an impactor, and therefore pores with $0.4 \mu \mathrm{m}$ diameter have high collection efficiency for all particle sizes (Cahill et al., 1977). Filters with $5 \mu \mathrm{m}$ pores have cutoff sizes around $1.5 \mu \mathrm{m}$ (Buzzard et al., 1981).

A high-precision analytical microbalance Mettler Toledo UMX2 with a resolution of $0.1 \mu \mathrm{g}$ was used to determine the particles' mass collected on the filters. Filters were discharged before weighing using a Mettler Toledo universal antistatic kit to minimize interference of charges on the measurement. The filters were weighed before and after the deposition of the resuspended particles for the determination of the concentration $\sigma$ in $\left[\mathrm{g} \mathrm{m}^{-2}\right]$, the mass deposited per unit of area on the surface of each filter. Blank filters were also used to control for possible error in the weighing procedure during the realization of the experiment.

\subsection{SEM analysis and size distribution}

Scanning electron microscopy (SEM) analysis with a microscope model JEOL 5600 with maximum resolution of $5 \mathrm{~nm}$ was used to obtain shape and size distribution of the particles. A semi-automatic procedure using PhotoImpact X3 and Image J software was used to determine the top view crosssectional area of each particle. From this area, the diameter of an equivalent circular area was derived. 


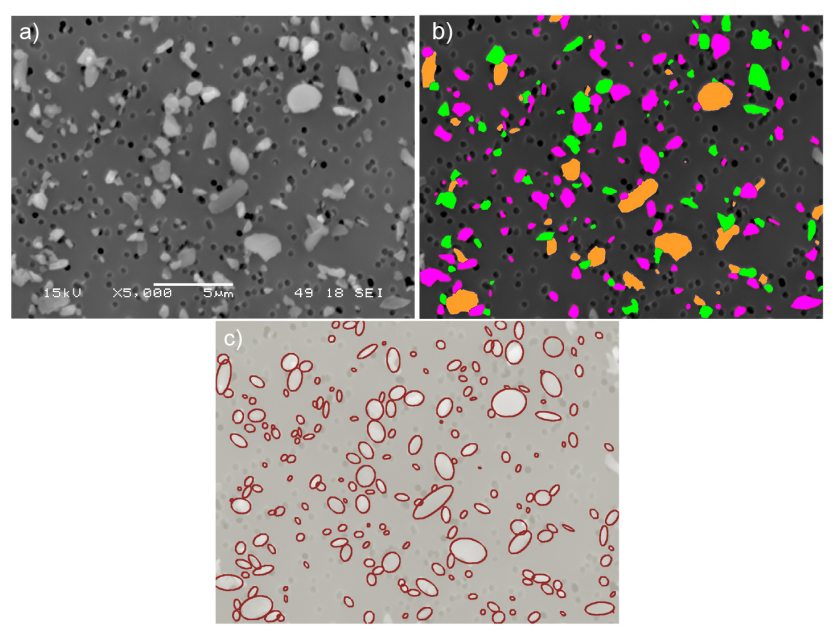

Figure 3. SEM images of the Eyjafjallajökull volcanic ash collected from the ground, resuspended and re-collected on filters. (a) Volcanic ash particles collected on a fine filter of $0.4 \mu \mathrm{m}$ pores. (b) Intermediate analysis by PhotoImpact X3 software with particles separated by colors. (c) Analyzed particles using ImageJ software, ellipses are fitted to the particles and top-view cross-sectional area and aspect ratio of each particle is derived.

The analysis of particle size distribution is done in two steps. PhotoImpact X3 is used to identify individual particles and manually separate those particles that are too close to each other or overlap, particles partially on the border of the figure, and particles that do not contrast well with the background of the image. ImageJ software is used subsequently to measure the area and aspect ratio of all the identified particles.

Figure 3 shows an example of the process of particle identification with PhotoImpact X3 and the posterior analysis of particle's size with ImageJ for a fine filter. Black circles on the images are the filter pores, while the particles are shown in white. The second image shows that overlapped particles or particles very close to each other can be separated by the software PhotoImpact X3, the separation is made by setting the particles in different colors. Finally the ImageJ software is applied to each set to obtain the cross-sectional area and aspect ratio of the particles.

Top-view SEM images do not provide information about the depth of the particles deposited on the filters, i.e., their third dimension. To gain some insight about this characteristic, we analyzed a set of particles using two images of SEM: the top-view image and an additional image taken of the same particles by tilting the sample inside the microscope. The ratio between the top-view mean diameter " $\mathrm{d}$ " and the height " $h$ " of the particles was obtained by an analysis of the particles' projected area from the two images. From there we found that there is a preferential orientation for the particle deposition on the filters with $\mathrm{d} / \mathrm{h}$ smaller than 1 for around $75 \%$ of the particles. We estimated the ash particles' volume

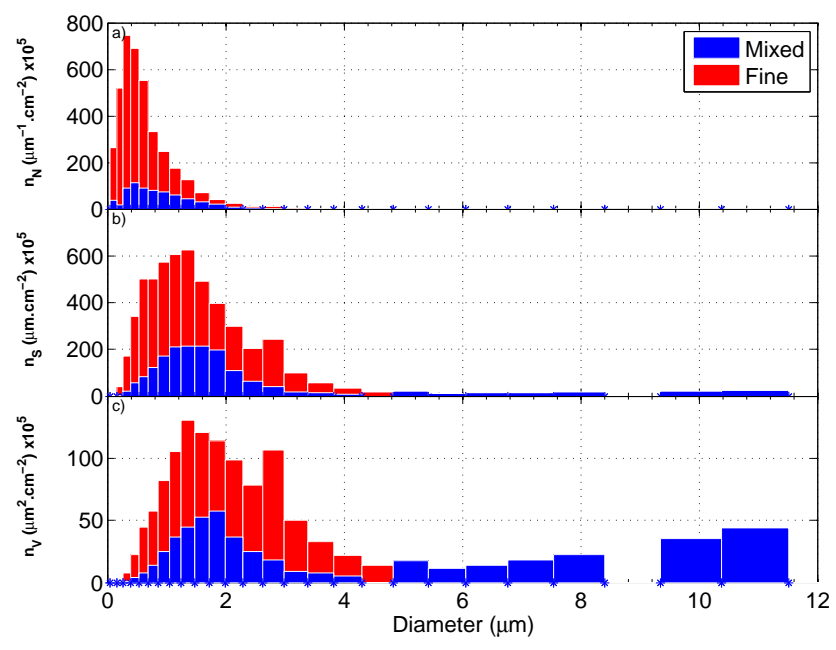

Figure 4. Particle's number, surface area, and volume distribution vs. particle diameter (per $\mathrm{cm}^{2}$ of filters) obtained by analysis of SEM images for a fine and a coarse filter of the Eyjafjallajökull volcanic ash. Distributions are normalized by the width of the bins to show the area below the curve proportional to the number concentration, following the form discussed in Seinfeld and Pandis (1998).

as $v(r)=A \cdot r$, where $A$ is the top-view cross-sectional area of the particle and $r$ is the particle's radius extracted from the top-view cross-sectional area of each particle.

Figure 4 shows the particles' number, surface area, and volume distributions for the fine (red) and mixed (blue) fraction based on an analysis of about 3000 particles. Most of the particles collected on the fine filter have diameter below $2 \mu \mathrm{m}$, while the coarse filter contains particles that overlap with the distribution from the fine filter but also extend to $11 \mu \mathrm{m}$ of diameter. Therefore we refer to particles in the coarse filter as mixed.

\subsection{Grain density of the volcanic ash}

The density $\rho$ of the volcanic ash was measured using a custom-made instrument similar to a gas pycnometer (Chang, 1988). Our system consists of a vessel of adjustable volume with a resolution of $0.1 \mathrm{~mL}$ and a barometer with a resolution of $0.5 \mathrm{psi}$. The volume $V_{\text {ash }}$ of a sample was obtained by measuring the variation of the volume $(\Delta V)$ required to double the pressure of the vessel, as illustrated in Fig. 5. We repeat this procedure with and without the volcanic ash particle inside the vessel. $V_{\text {ash }}$ was found as $V_{\text {ash }}=V_{\mathrm{C}}-\Delta V \cdot P_{2} /\left(P_{2}-P_{1}\right)$, where $V_{\mathrm{C}}$ is the total volume of the vessel and $P_{1}$ and $P_{2}$ are the initial and final pressures in the vessel with a sample of ash inside it. We determined the ash's density as $\rho=M_{\text {ash }} / V_{\text {ash }}$, where $M_{\text {ash }}$ is the mass of the analyzed sample. The uncertainty of the particle's grain density was calculated from uncertainties of the measurements of mass, volume and pressure. 


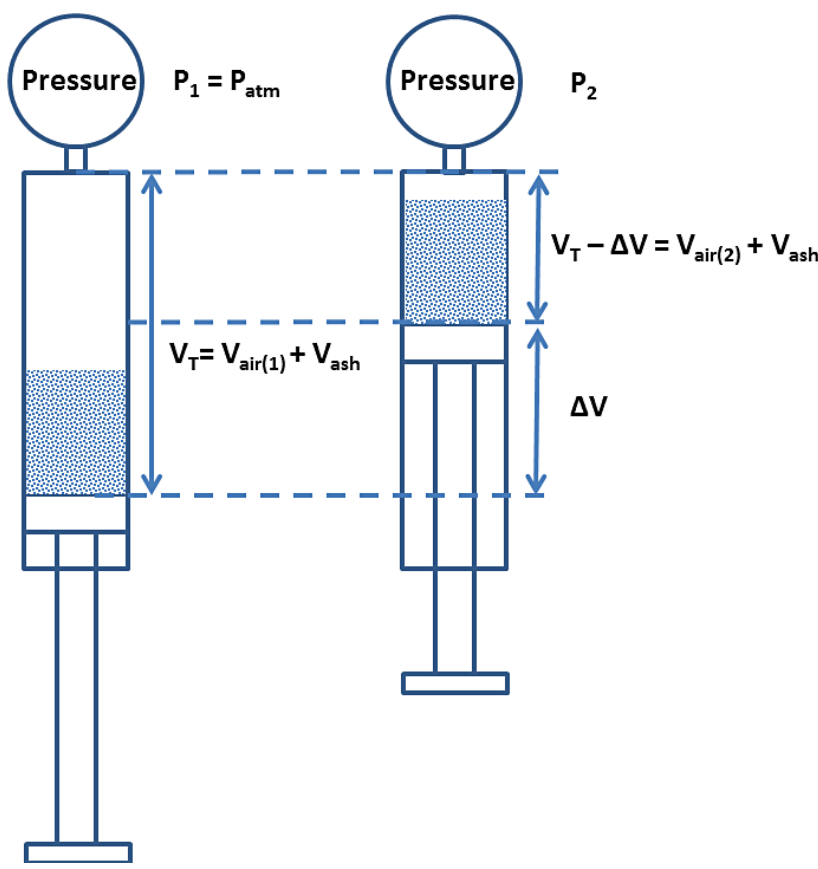

Figure 5. Schematic drawing of the experimental procedure for determination of the grain density of the volcanic ash.

The measured volcanic ash density was $2.16 \pm 0.13 \mathrm{~g} \mathrm{~cm}^{-3}$. This value is smaller than what is usually used in the literature for ash samples from the Eyjafjallajökull volcano, which is $2.6 \mathrm{~g} \mathrm{~cm}^{-3}$ (Gasteiger et al., 2011; Bukowiecki et al., 2011) or $2.4 \mathrm{~g} \mathrm{~cm}^{-3}$ (Gudmundsson et al., 2010). According to Shipley et al. (1982), values of particles' grain density can vary significantly (from 0.7 to $3.2 \mathrm{~g} \mathrm{~cm}^{-3}$ ) for volcanic ash. Discrepancies in the values of density applied for volcanic ash might be related to the scarcity of direct measurements of this quantity in the literature. In general, the density of the material is taken from assumptions based on the analysis of composition of the particles.

\subsection{Spectral light absorption via optical reflectance measurements}

The spectral light absorption of the volcanic ash particles was investigated by measuring the reflectance of the Nuclepore ${ }^{\circledR}$ filters as a function of the volcanic ash collected mass. A broadband light source was used to shine light on these filters. The reflected light from the loaded filters was analyzed comparatively to blank filters' reflectivity. Two spectrometers with different broadband illuminators were used: an Avantes AvaSpec 2048, with ultra-violet (UV) starting from $300 \mathrm{~nm}$ to near-infrared wavelengths (NIR) up to $1100 \mathrm{~nm}$, with a high-power UV-VIS light source from Hamamatsu model L10290, and a FieldSpec Pro from Analytical Spectral Devices with a range of 350 to $2500 \mathrm{~nm}$ with a reflectance lamp from ASD Inc.

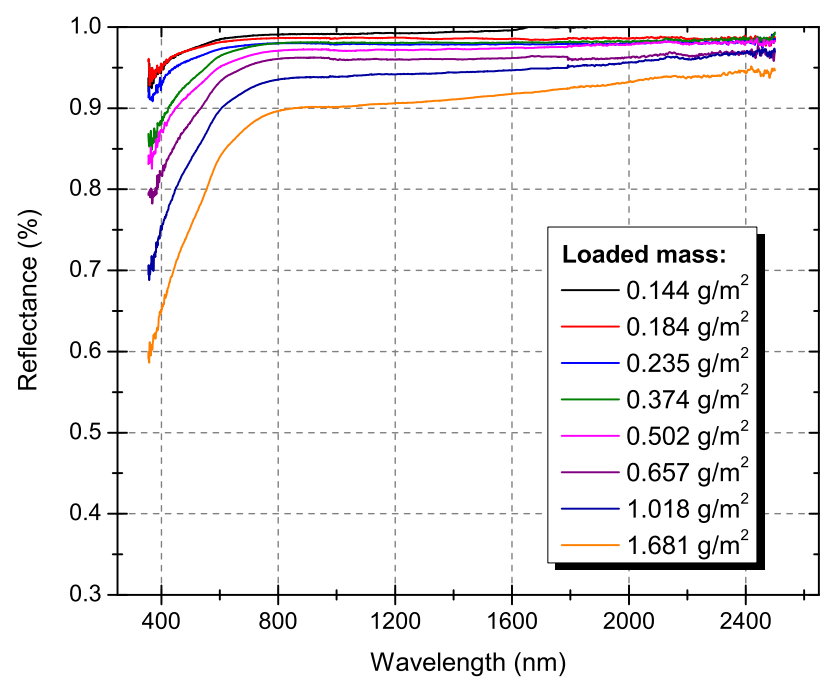

Figure 6. Spectral reflectance of the volcanic ash Eyjafjallajökull for fine filters according to the loaded mass per unit area $\sigma$ of each filter in $\left[\mathrm{g} \mathrm{m}^{-2}\right]$. Each curve represents the average over 25 measurements of reflectance over the same filter. Uncertainties on the reflectance were estimated to be a maximum of $2.0 \%$ for the full wavelength range. These uncertainties arise mainly from nonflatness of the filters when placed for measurements.

Figure 6 shows the spectral reflectance for the Eyjafjallajökull volcanic ash collected on several filters with different mass loadings. These measurements were performed at zenith angle of $10^{\circ}$ while the light source illuminated the filter at zenith angle of $45^{\circ}$ and same azimuth. Each curve is an average of 25 measurements of reflectance, reducing noise levels to less than $0.5 \%$. For these measurements the filter should be as flat as possible; waves in the surface of the filter will increase the variability of the reflectance and increase uncertainties. The total uncertainty in these measurements is mainly driven by the the smoothness of the filter and homogeneity of particles collected on the filter. These were estimated to be of maximum $2 \%$.

We can see from these results that most of the attenuation occurs for short wavelengths and we will assume that the total attenuation is due mainly to absorption. The reasoning behind this assumption is based on three properties of our experimental set-up: (1) light scattered forward by the particles will most likely hit the white surface of the filter underneath and scatter backward on its path back to the spectrometer. (2) Reflectance of aerosol particles on filters was measured at different viewing angles (from 10 to $45^{\circ}$ from nadir) and found to be constant within $5 \%$. These measurements demonstrated that the angular effects of phase function and/or filter BRDF (bidirectional reflectance distribution function) are not significant in this range. (3) Multiple scattering effects are minimized in the Nuclepore filters due to particles being collected on the surface of the filters 

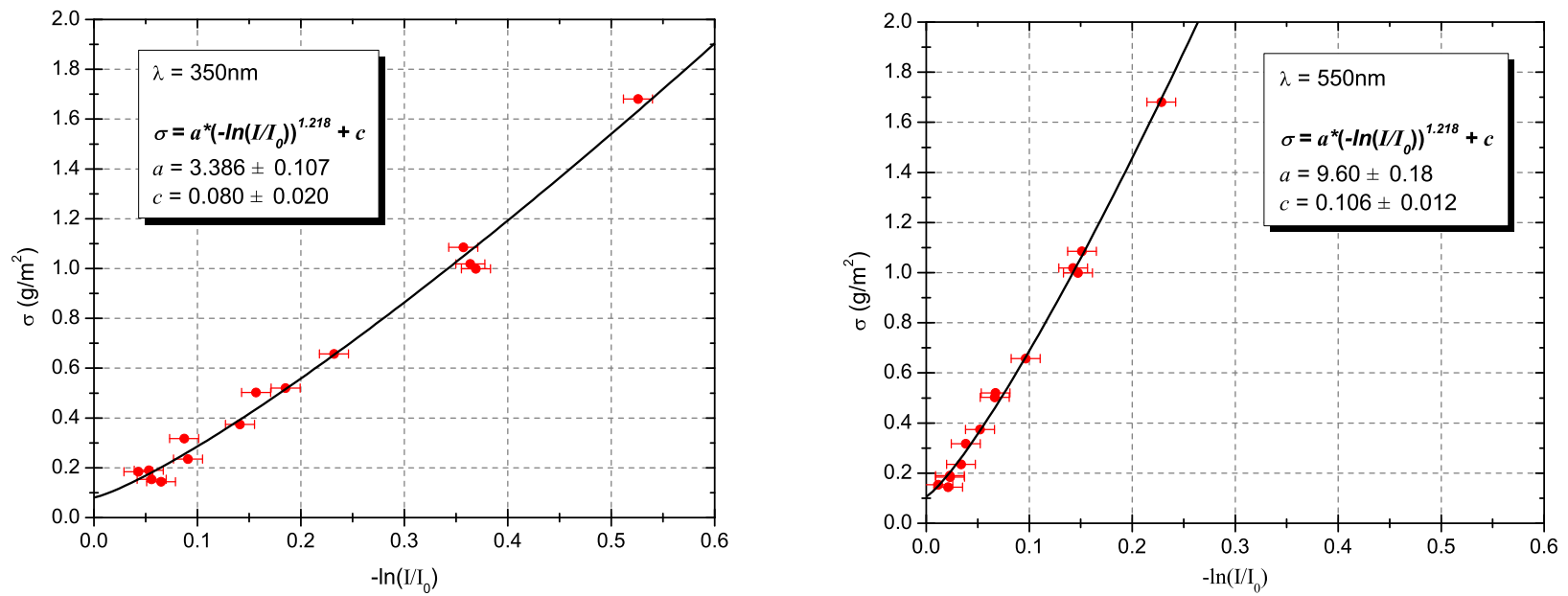

Figure 7. Power law fitting of the concentration $\sigma$ in $\left[\mathrm{g} \mathrm{m}^{-2}\right]$ vs. the logarithm of the reflectance $\left(I / I_{0}\right)$ using $b=1.218$ and $a$ and $c$ as free parameters. These examples are for fine particles of the Eyjafjallajökull volcanic ash for two wavelengths: 350 and $550 \mathrm{~nm}$. Error bars are the combined uncertainties of the reflectances and loaded mass of particles on the filters.

(Martins et al., 2009). For this reason multiple scattering effects were neglected in this work.

Reid et al. (1998) shows a validation of the reflectance method comparing it with a standard extinction cell and a nephelometer. According to their analysis, the absorption obtained by reflectance measurements was in good agreement with the extinction cell measurements for a large range of aerosol loading.

According to Martins et al. (2009), when particles are attached to the filters, a correction of the Lambert-Beer law is needed to describe the absorption of light by these particles. This correction was derived using an empirical power coefficient $b=1.218$ and it is described in this paper as the empirical power law method, where the relationship between $\sigma$ and the mass absorption efficiency $\alpha_{\text {abs }}$ is given by Eq. (1).

$\sigma=\frac{G}{2 \alpha_{\mathrm{abs}}}\left[-\ln \left(I / I_{0}\right)\right]^{b}+c$

The mass absorption efficiency $\alpha_{\mathrm{abs}}$ in $\left[\mathrm{m}^{2} \mathrm{~g}^{-1}\right]$ can be obtained by the relationship between the collected aerosol mass per unit of area on the surface of the filter $\sigma\left[\mathrm{g} \mathrm{m}^{-2}\right]$ and the logarithm of the reflectance $\left(I / I_{0}\right)$ for each wavelength. Here $I / I_{0}$ is the ratio of the reflectance of a filter with ash deposited on it and one clean filter. The geometrical factor $G$ described in Martins et al. (2009) was determined to equal 1 for a large range of geometries, including the one used in this work. The parameter $c$ is a constant to take into account a possible offset in the mass of the filters, for instance due to an error in blank subtraction.

Figure 7 shows examples of power law fittings for 350 and $550 \mathrm{~nm}$ using the empirical power law method for fine filters with different loaded masses. The error bars were obtained combining the uncertainties of the reflectance measurements and the loaded mass. This fit was performed for each wave- length every $1 \mathrm{~nm}$ from $300 \mathrm{~nm}$ to $2500 \mathrm{~nm}$, allowing us to obtain the spectral dependence of $\alpha_{\mathrm{abs}}$ from the fitted parameter $a$, as $\alpha_{\mathrm{abs}}=G /(2 a)$.

Figure 8 shows the resulting mass absorption efficiency obtained from the empirical power law method applied for each measured wavelength, as exemplified in Fig. 7. The uncertainties were estimated from the error in fitting the coefficient $a$. The results show enhanced UV absorption features for fine particles. This is in agreement with the fact that large particles, in the UV-VIS wavelength range, lower the absorption efficiency due to incomplete light penetration into the particle (Moosmüller et al., 2011).

Another independent method to obtain the mass absorption efficiency is based on the particles' size distribution, referred to as size distribution method. The mass absorption (or scattering, or extinction) efficiency of the aerosols $\left(\alpha_{i}\right.$ in $\left(\mathrm{m}^{2} \mathrm{~g}^{-1}\right)$, where the index $i$ indicates either absorption, scattering or extinction) can be written in terms of the particle number size distribution $\left(n(r)\right.$ in $\left(\right.$ particles $\left.\left.\mathrm{m}^{-2}\right)\right)$, geometrical cross-sectional area $\left(A(r)\left[\mathrm{m}^{2}\right]\right)$, volume of each particle $\left(v(r)\left(\mathrm{m}^{3}\right)\right)$ and grain density $\left(\rho\left(\mathrm{g} \mathrm{m}^{-3}\right)\right)$ of the material by

$\alpha_{i}=\frac{\int_{0}^{\infty} n(r) Q_{i}(x, m) A(r) \mathrm{d} r}{\int_{0}^{\infty} n(r) \rho v(r) \mathrm{d} r}$,

where $Q_{i}$ is the efficiency coefficient representing the weighting factor for the probability of interaction of light with particles. $Q_{i}$ depends on the particle size parameter $x=2 \pi r / \lambda$, on the particle's shape, and on the complex refractive index of the particle material $m=n-i k$.

Volcanic ash particles have a diversity of shapes, as can be seen in Fig. 3. The relation between shape of the particles and their absorption properties is not fully understood for complicated shape distributions. Here we used the comparison between spherical particles and spheroids to assess the 


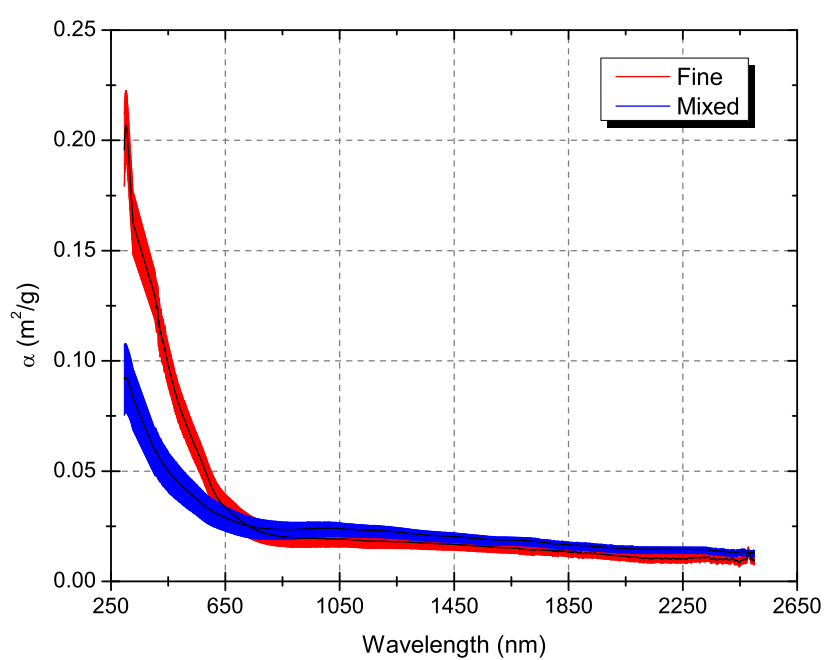

Figure 8. Spectral mass absorption efficiency $\left(\alpha_{\mathrm{abs}}\right)$ for mixed and fine particles of the Eyjafjallajökull volcanic ash collected on filters. Uncertainties were estimated by propagating the error of the parameter $a$ obtained from the power law fitting, shown as error bands.

sensitivity of our retrieved $\operatorname{Im}(m)$ to particle shape. $Q_{\text {abs }}$ was calculated using (1) Mie-Lorenz theory, with the assumption of spherical particles, and (2) T-matrix, with the assumption of spheroids.

\subsection{Refractive index derivation}

The $\operatorname{Im}(m)$ for fine and mixed particles of the Eyjafjallajökull volcanic ash was obtained by an iterative process that minimizes the difference between $\alpha_{\text {abs }}$ derived from Eq. (1) and $\alpha_{\text {abs }}$ obtained from Eq. (2) for each wavelength.

We performed the minimization to obtain $\operatorname{Im}(m)$ and $\operatorname{Re}(m)$ simultaneously, varying $\operatorname{Im}(m)$ in steps of 0.00001 and $\operatorname{Re}(m)$ in steps of 0.01 with values ranging from 1.5 to 2.0 to include most of the values of $\operatorname{Re}(m)$ found in the literature. Since the sensitivity to obtain $\operatorname{Re}(m)$ is small, we performed a second minimization, with $\operatorname{Re}(m)$ fixed at the average value we found, $\operatorname{Re}(m)=1.68$. To estimate the influence of the $\operatorname{Re}(m)$ on the minimization procedure, we repeat the minimization considering a variation of \pm 0.1 in $\operatorname{Re}(m)$. We observed that this variation produces a \pm 0.00025 change in $\operatorname{Im}(m)$.

The minimization procedure, based on the difference between $\alpha_{\text {abs }}$ derived from Eq. (1) and $\alpha_{\text {abs }}$ obtained from Eq. (2), was reached with a maximum difference of $10^{-4}$, which is less then $0.2 \%$ of $\alpha_{\mathrm{abs}}$.

Figure 9 shows the results obtained for $\operatorname{Im}(m)$ with $\operatorname{Re}(m)$ kept fixed at its mean value and assuming spherical particles. $\operatorname{Im}(m)$ is observed to be higher in the wavelength range below $500 \mathrm{~nm}$ with a strong increase in the UV region. A minimum of absorption is observed at $\lambda=875 \mathrm{~nm}$ for fine particles, and at $\lambda=700 \mathrm{~nm}$ for the mixed ones. For shorter wavelengths, $\operatorname{Im}(m)$ for the fine particles is higher than the mixed

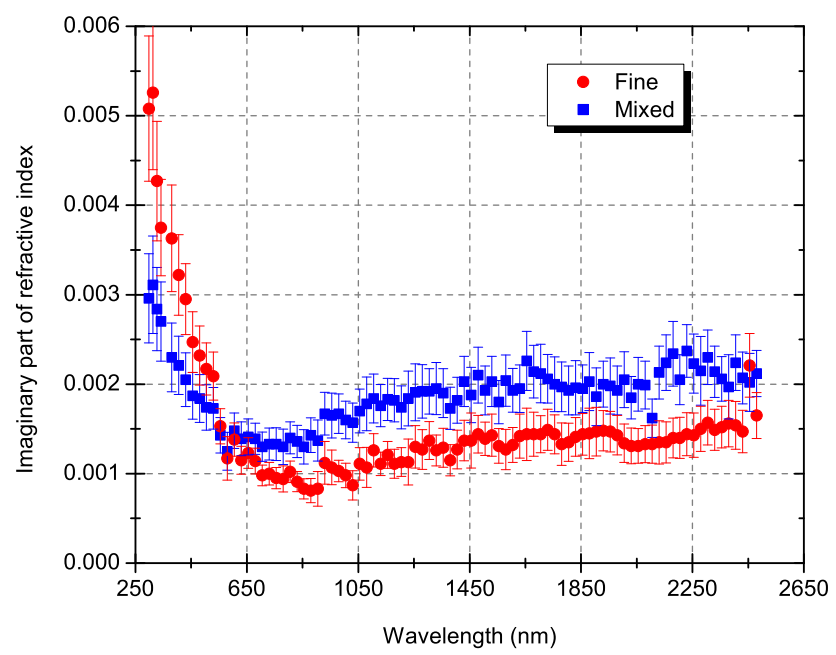

Figure 9. Imaginary part of the complex refractive index for mixed and fine particles using Mie theory with $n=1.68$ and density $\rho=$ $2.16 \mathrm{~g} \mathrm{~cm}^{-3}$. The error bars of the imaginary part of the complex refractive index were estimated by studying the sensitivity of the minimization method to the uncertainties of the real part of the refractive index, the mass absorption efficiency, the particles' crosssectional area, volume, and density.

ones with an inversion for longer wavelengths. The crossover is at about $\lambda=550 \mathrm{~nm}$.

The uncertainties on the retrieval of $\operatorname{Im}(m)$ were estimated considering the main sources of errors in our retrieval: the real part of the refractive index, the mass absorption efficiency, and the particles' cross-sectional area, volume, and density. These uncertainties were added quadratically and are shown as error bars in Fig. 9.

In the literature, the refractive index of the Eyjafjallajökull volcanic ash was reported as $\operatorname{Re}(m)=1.58(2)$ and $\operatorname{Im}(m)$ in the range $0.002-0.015 i$ (at $550 \mathrm{~nm}$ ), derived using the particle soot absorption photometer inversion method (Weinzierl et al., 2012; Petzold et al., 2009, 2011). In Schumann et al. (2011) the Eyjafjallajökull volcanic ash plume was studied assuming absorbing particles with a refractive index $1.59+0.004 i$ and non-absorbing particles with refractive index $1.59+0 i$ at $636 \mathrm{~nm}$. Differences on the refractive index between fine and coarse particles due to chemical composition variations were also discussed by Newman et al. (2012); this study adopted $1.52+0.0015 i$ for coarse mode and $1.43+0.00 i$ for fine mode, specified across all UV-visible wavelengths. Our results of $\operatorname{Im}(m)$ are partially in agreement with values found in the literature for the specific wavelengths measured by these other studies. Comparatively to other volcanic ashes, our $\operatorname{Im}(m)$ in the UV has the same order of magnitude of previous laboratory measurements for the Mount Spurr volcano (Krotkov et al., 1999). However, our results have smaller $\operatorname{Im}(m)$ than Mount St. Helens and Fuego ashes measured in the 1980s (Patterson et al., 1981, 1983). 


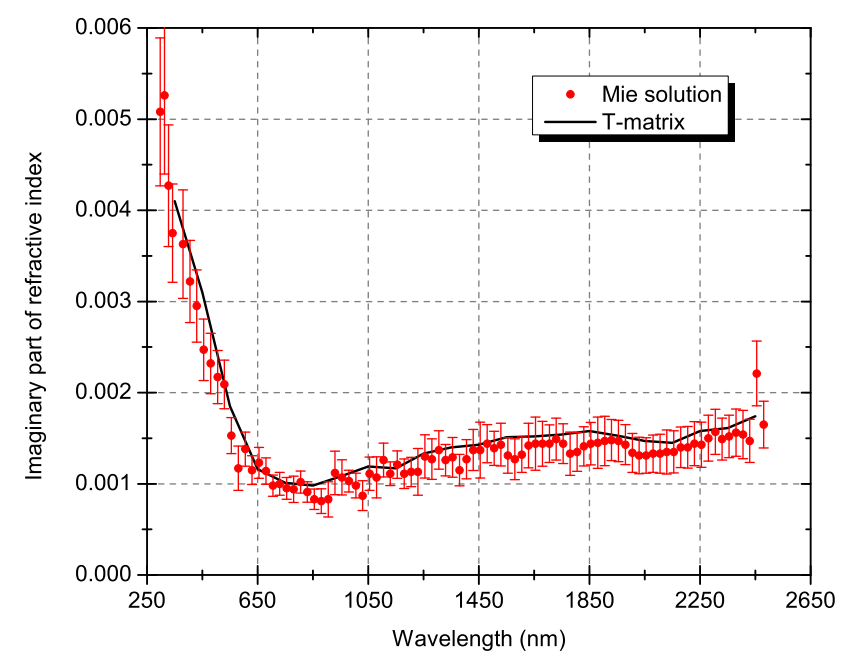

Figure 10. Imaginary part of the complex refractive index calculated for fine particles by Mie theory and T-Matrix (for an aspect ratio of 1.5).

The T-matrix method was also applied assuming randomly oriented ellipsoidal particles using the extended-precision code. A modified gamma distribution was fitted to the measured size distribution of the particles shown in Fig. 4 corrected for the "equal-volume sphere radius" distribution, as defined in Mishchenko et al. (1998). Using the SEM images, the median of the aspect ratio distribution was obtained calculating the axial ratio of each particle. The most probable value for the aspect ratio was found to be $f=1.5$ for both fine and mixed distributions and this value was used in the Tmatrix code. The ellipsoids considered by the T-matrix code are created by rotating ellipses about one of their axis and they are completely defined by the "equal-volume sphere radius" distribution and the axial ratio. In this study we consider ellipses rotating about their minor axis, creating oblate spheroids. Implications of the assumption of $f=1.5$ were evaluated in Sect. 3, where other values of $f=1.8$ and 3.0 were also used for T-matrix calculations.

Figure 10 overlaps $\operatorname{Im}(m)$ derived using Mie theory and T-matrix for fine particles. The high agreement indicates, at least in the range considered, that a change of aspect ratio from $f=1$ (spherical case) to 1.5 (oblate spheroid) does not produce significant variation in $\operatorname{Im}(m)$. The agreement between Mie theory and T-Matrix for fine particles was also observed by Krotkov et al. (1999). In the mixed mode, the combination of large particles $(d>3 \mu \mathrm{m})$ and smaller wavelengths (below $1 \mu \mathrm{m}$ ) generated large size parameters for which the T-matrix code produced convergence errors that did not allow the final calculations of the absorption efficiencies.

We estimated that the uncertainties on the imaginary part of the refractive index for the T-Matrix calculation have the same magnitude as the uncertainties estimated for Mie the-

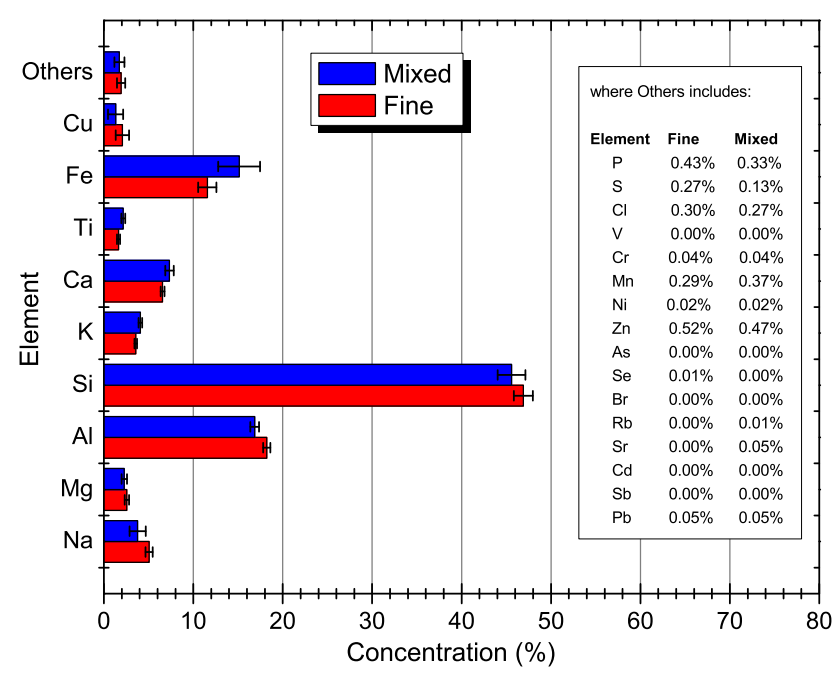

Figure 11. Fraction of the mass of each element in relation to the total collected mass. The error bars represent one standard deviation of the concentration measured for different filters.

ory. Uncertainties for T-Matrix were not explicitly shown with the curves in Figs. 10 and 13b in order to make the reading of this figure easier.

\subsection{Compositional analysis by $X$-ray fluorescence}

Energy dispersive X-ray fluorescence analysis (EDXRF) of the fine and mixed particles was used to investigate differences in chemical composition between both modes. Xray fluorescence analyses of 12 fine filters and 4 coarse filters were performed at the Atmospheric Physics Laboratory at University of Sao Paulo on an Epsilon 5 PanAnalytical EDXRF spectrometer.

Figure 11 shows the average concentration fraction (for fine and mixed-mode particles) relative to the total mass collected on the filters. $\mathrm{Si}, \mathrm{Al}$ and $\mathrm{Fe}$ are the three major elements that together represent up to $35 \%$ of the total aerosol mass. The error bars represent 1 standard deviation of the concentration measured for different filters.

The ratios between the fine and mixed modes' average concentrations, calculated based only on the mass detected by EDXRF (from $\mathrm{Na}$ to $\mathrm{Pb}$ ) presented in Fig. 12, show the variation between fine and mixed modes' elemental concentrations. The uncertainties of the concentrations' ratios between fine and mixed mode were obtained by direct error propagation of the concentrations. The results show a tendency for low atomic number elements to dominate in the fine particles, while higher atomic number elements dominate in the mixed-mode particles. Lower levels of $\mathrm{Na}, \mathrm{Mg}$, and $\mathrm{Al}$ for mixed-mode particles might be explained by a possible size-dependent self-absorption enhancement not taken into account during the EDXRF analysis. The higher ratio obtained for sulfur is in agreement with the presence of the sulfate particles (around $150 \mathrm{~nm}$ ) that are produced by 


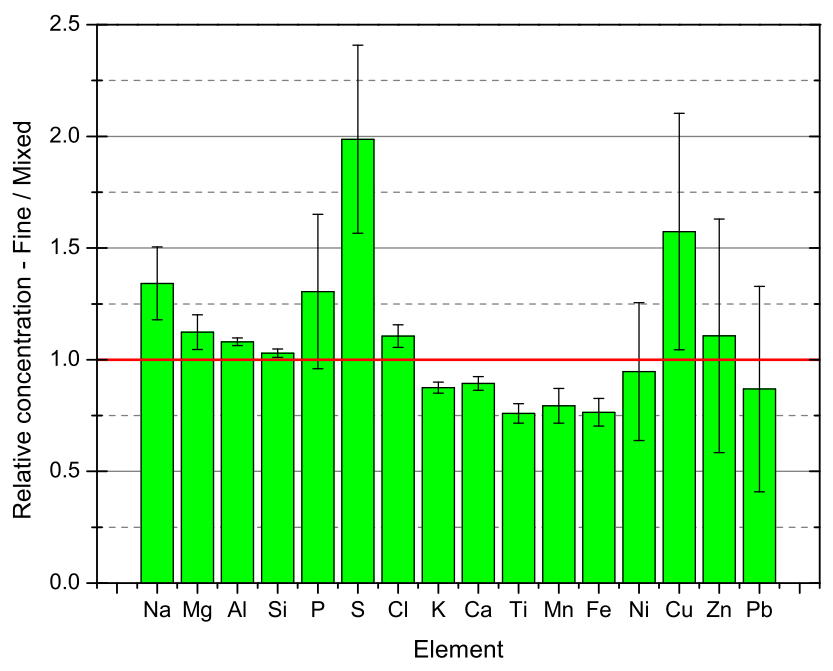

Figure 12. Relative mass concentration between fine and mixed modes. The error bars were calculated from direct error propagation from the measurement of concentrations.

sulfuric acid drops and they are expected to be concentrated mostly in the fine mode (Weinzierl et al., 2012).

Samples with fine and mixed-mode particles of the volcanic ash were subjected to thermal optical carbon analysis, but no significant amount of carbon was found.

\section{Discussion}

We found that the difference of mass absorption efficiency for mixed and fine particles becomes more pronounced in the wavelength range below $600 \mathrm{~nm}$. These differences in the mass absorption efficiency between the modes should not be attributed only to differences in the refractive index, but also to the size distributions of the particles (Moosmüller et al., 2011).

The retrieved $\operatorname{Im}(m)$ shows spectral differences of up to $0.002 i$ for fine and mixed particles. The EDXRF analysis also shows different compositions for fine and mixed-mode particles, which relates to the difference in refractive index. This finding is corroborated by other studies of volcanic ash from the same volcanic eruption that showed differences of compositions between the modes (Schumann et al., 2011; Newman et al., 2012). Further studies and discussions on this dependence of particles' composition with their size in minerals can be found in Kandler et al. (2009).

It is also important to discuss the assumptions of the particles' shapes for the retrieval of the refractive index. The retrieval initially considered all particles as spheres, allowing for the retrieval of $\operatorname{Im}(m)$ using Mie theory. The sensitivity of the retrieval of $\operatorname{Im}(m)$ to non-spherical particles was studied using the T-matrix code. This study was done for the fine mode only. A constant aspect ratio $f=1.5$ was selected initially as a representative value for fine-mode aerosols based on the median of the measured aspect ratio distribution measured from the scanning electron microscopy pictures of the particles (Fig. 13a). In order to evaluate the effect of the nonsphericity of the particles, Fig. 13b shows the retrieval of $\operatorname{Im}(m)$ considering higher aspect ratios $f=1.8$ and $f=3.0$ for this analysis. We found that $f=1.8$ is the highest value of $f$ with which we could run T-matrix without convergence problems for the entire range of wavelengths studied in this work. By considering $f=3.0$ as the representative aspect ratio of our collection of particles, we are certainly overestimating the effects of shape on the retrieval, given that only $0.6 \%$ of the particles were found to have an aspect ratio higher than $f=3.0$. This value of $f$ limited us to obtaining results for wavelengths only above $1100 \mathrm{~nm}$. As can be seen in Fig. 13b, the effects of assumptions on the shape of the particles are not negligible. But even the most conservative analysis considering $f=3.0$ produced results that are within the uncertainties previously estimated for $\operatorname{Im}(m)$. Nevertheless, it is important to note that an aspect ratio of $f=3.0$ is not extreme for all types of particles in nature. As observed by Veghte and Freedman (2014), some clay particles with plate-like structures can have lateral aspect ratios between 4 and 9 .

This work measured the optical, microphysical and compositional properties of the sample we have available from the Eyjafjallajökull eruption, collected at $35 \mathrm{~km}$ from the volcano. Volcanic ash particles might be subjected to long-range transport effects, such as size and density selection. Therefore, it is unknown how directly applicable our results reported here are to the ash plume that occurred over Europe during this eruption. However, there are some studies that do at least link composition of the ash found in Europe with that collected in Iceland. Bukowiecki et al. (2011) reported that the average chemical composition of volcanic ash particles that reached Switzerland was very similar to a sample collected near the volcano. Also, Beeston et al. (2012) found evidence that the ash from the Eyjafjallajökull's eruption reached Slovenia (more than $2500 \mathrm{~km}$ away from the volcano) based on analyses of chemical composition of the aerosol collected in Slovenia after the eruption, which has shown properties similar to those from the Eyjafjallajökull eruption. These similarities in composition, near and far from the source, offer some support to the premise that the optical properties of the long-range transported aerosol do not vary significantly with the sample collected in the proximity of the volcano.

\section{Conclusions}

The results obtained show differences in the optical properties between fine and mixed fraction of the analyzed volcanic ash. These differences were observed in the spectral mass absorption efficiency and in $\operatorname{Im}(m)$. From 300 to $550 \mathrm{~nm}$, $\operatorname{Im}(m)$ for fine particles varies between 0.0015 and $0.0055 i$, 

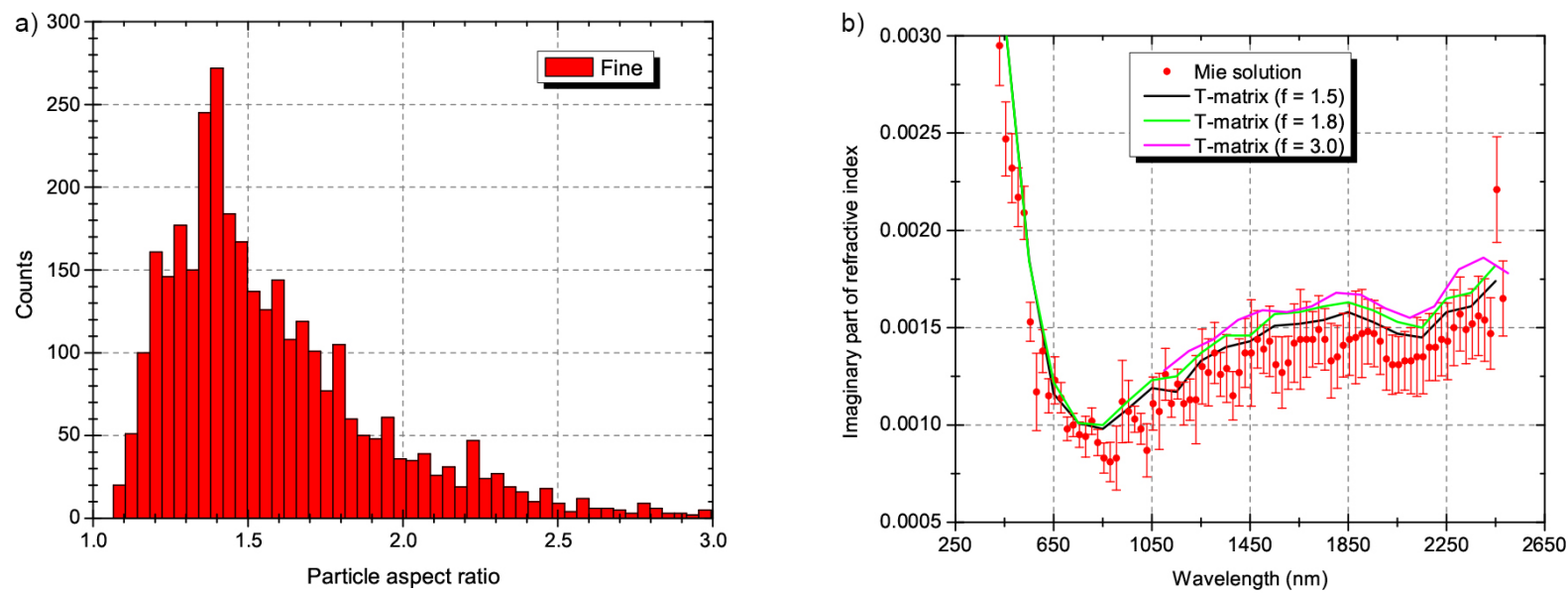

Figure 13. (a) Particles' shape distribution for the fine mode of the volcanic ash and (b) analysis of the imaginary part of the complex refractive index considering different aspect ratios $f$ for the T-matrix calculations of spheroidal particles. For $f=3$, the imaginary part of the complex refractive index was retrieved only for wavelengths above $1100 \mathrm{~nm}$ due to convergence issues of the T-matrix code for shorter wavelengths.

while for mixed particles the variation in the same wavelength interval is from 0.0015 to $0.003 i$. From $550 \mathrm{~nm}$ to $2500 \mathrm{~nm}, \operatorname{Im}(m)$ for mixed and fine modes overlaps and varies from 0.001 to $0.002 i$. The main sources of error in the derivation of $\operatorname{Im}(m)$ include constraining the real part of the refractive index, uncertainty in deriving the mass absorption efficiency, particle cross-sectional area, volume and density of the material. These errors combine to give us a spectrally dependent total uncertainty of $\operatorname{Im}(m)$ from \pm 0.00015 to $\pm 0.001 i$ for wavelengths 300 to $550 \mathrm{~nm}$ and \pm 0.0001 to $\pm 0.00025 i$ for wavelengths 550 to $2500 \mathrm{~nm}$. Assuming spherical or spheroid particle shapes in calculations of the mass absorption efficiency, both yield similar $\operatorname{Im}(m)$ for fine particles. Deviations in the $\operatorname{Im}(m)$ are observed when the mean aspect ratio is changed from 1.5 to 3 in the T-matrix code, but this deviation is within the uncertainties of the measurements.

EDXRF analysis shows that fine and mixed particles have compatible composition for most of the elements. Notable differences are observed for $\mathrm{Ca}$ and $\mathrm{Fe}$ (the fourth and the fifth most abundant element), the ratio of their concentrations seems to indicate slightly higher concentrations of $\mathrm{Ca}$ and $\mathrm{Fe}$ in the mixed particles. The double concentration of sulfur in the fine particles, even though in small amounts, is in agreement with the expected higher concentration of fine sulfur particles produced by sulfuric acid drops. Further studies are needed to explain the relationship between the differences of composition and optical properties observed between fine and mixed particles.

These results represent a comprehensive and consistent set of direct measurements of spectral refractive index, size distribution, shape and elemental composition of volcanic ash. This fundamental information will enable better constraints on remote sensing products and model representation of the ash, leading to more reliable calculations of ash plume transport in the future and better characterization of the role of volcanic ash in Earth's energy balance and climate change. These results represent a comprehensive and consistent set of direct measurements of spectral refractive index, size distribution, shape and elemental composition.

Acknowledgements. We acknowledge funding support from the NASA Atmospheric Composition Program (Investigation of Aerosol Spectral Absorption Properties from UV to NIR, grant number NNX07AT47G) and from the JCET/UMBC 2013-14 Graduate Fellowship. We thank the scientific and technical support of the LACO team at UMBC (especially D. Cieslak and S. Buczkowski), and the LFA team at University of Sao Paulo (Ana Loureiro and Andrea Arana). We also thank U. Schumann from DRL and H. Olafsson for providing samples collected in Iceland and for providing information about the collection process. Y. Ben-Ami thanks the support of the NASA Postdoctoral Program at the Goddard Space Flight Center.

Edited by: A. Laskin

\section{References}

Andreae, M. O. and Crutzen, P. J.: Atmospheric Aerosols: Biogeochemical Sources and Role in Atmospheric Chemistry, Science, 276, 5315, 1052-1058 doi:10.1126/science.276.5315.1052, 1997.

Andreae, M. O. and Rosenfeld, D.: Aerosol-cloudprecipitation interactions. Part 1. The nature and sources of cloud- active aerosols, Earth-Sci. Rev., 89.1, 13-41 doi:10.1016/j.earscirev.2008.03.001, 2008.

Ansmann, A., Tesche, M., Groß, S., Freudenthaler, V., Seifert, P., Hiebsch, A., Schmidt, J., Wandinger, U., Mattis, I., Muller, D., and Wiegner, M.: The 16 April 2010 major volcanic ash plume 
over central Europe: EARLINET lidar and AERONET photometer observations at Leipzig and Munich, Germany, Geophys. Res. Lett., 37, L13810, doi:10.1029/2010GL043809, 2010.

Beeston, M., Grgić, I., van Elteren, J.T., Iskra, I., Kapun, G., and Močnik, G.: Chemical and morphological characterization of aerosol particles at Mt. Krvavec, Slovenia, during the Eyjafjallajökull Icelandic volcanic eruption, Environ. Sci. Pollut. R, 19.1, 235-243, doi:10.1007/s11356-011-0563-8, 2012.

Bellouin, N. A, Jones, J. H, and Christopher, S. A.: Updated estimate of aerosol direct radiative forcing from satellite observations and comparison against the Hadley Centre climate model, J. Geophys. Res., 113, D10205, doi:10.1029/2007JD009385, 2008.

Bond, T. C, Bergstrom, R. W, and Christopher, S. A.: Light Absorption by Carbonaceous Particles: An Investigative Review, Aerosol Sci. Tech., 40, 27-67, doi:10.1080/02786820500421521, 2006.

Boucher, O., Randall, D., Artaxo, P., Bretherton, C., Feingold, G., Forster, P., Kerminen, V. -M., Kondo, Y., Liao, H., Lohmann, U., Rasch, P., Satheesh, S. K., Sherwood, S., Stevens, B. and Zhang, X. Y.: Clouds and Aerosols, in: Climate Change 2013: The Physical Science Basis. Contribution of Working Group I to the Fifth Assessment Report of the Intergovernmental Panel on Climate Change, edited by: Stocker, T. F., Qin, D., Plattner, G. K., Tignor, M., Allen, S. K., Boschung, J., Nauels, A., Xia, Y., Bex V. and Midgley, P. M., Cambridge University Press, Cambridge, United Kingdom and New York, NY, USA, 2013.

Bukowiecki, N., Zieger, P., Weingartner, E., Jurányi, Z., Gysel, M., Neininger, B., Schneider, B., Hueglin, C., Ulrich, A., Wichser, A., Henne, S., Brunner, D., Kaegi, R., Schwikowski, M., Tobler, L., Wienhold, F. G., Engel, I., Buchmann, B., Peter, T., and Baltensperger, U.: Ground-based and airborne in-situ measurements of the Eyjafjallajökull volcanic aerosol plume in Switzerland in spring 2010, Atmos. Chem. Phys., 11, 10011-10030, doi:10.5194/acp-11-10011-2011, 2011.

Buzzard, G. H. and Parker, R. D.: A two stage particle fractinator using large pore nuclepore surfaces, US Environmental Protection Agency, Environmental Sciences Research Laboratory, Research Triangle Park, N.C., USA, 1981.

Cahill, T. A., Ashbaugh, L. L., Barone, J. B., Eldred, R. A., Feeney, P. J., Flocchini, R. G., Goodart, C., Shadoan, D. J., and Wolfe, G. W.: Analysis of Respirable Fractions in Atmospheric Particulates via Sequential Filtration, J. Air Pollut. Control Assoc., 27, 675-678, doi:10.1080/00022470.1977.10470474, 1977.

Casadevall, T. J.: Volcanic Ash and Aviation Safety, in: Proceedings of the First International Symposium on Volcanic Ash and Aviation Safety, US Geological Survey USGS Bulletin 2047, 1-6, 1994.

Chang, C. S.: Measuring density and porosity of grain Kernels using a gas Pycnometer, Cereal Chem., 65, 13-15, 1988.

Chin, M., Kahn, R. A., and Schwartz, S. E.: Atmospheric Aerosol Properties and Climate Impacts, A Report by the U.S. Climate Change Science Program and the Subcommittee on Global Change Research. National Aeronautics and Space Administration, Washington, D.C., USA, 128 pp., 2009.

Chin, M., Diehl, T., Tan, Q., Prospero, J. M., Kahn, R. A., Remer, L. A., Yu, H., Sayer, A. M., Bian, H., Geogdzhayev, I. V., Holben, B. N., Howell, S. G., Huebert, B. J., Hsu, N. C., Kim, D., Kucsera, T. L., Levy, R. C., Mishchenko, M. I., Pan, X., Quinn, P. K., Schuster, G. L., Streets, D. G., Strode, S. A., Torres, O., and Zhao,
X.-P.: Multi-decadal aerosol variations from 1980 to 2009: a perspective from observations and a global model, Atmos. Chem. Phys., 14, 3657-3690, doi:10.5194/acp-14-3657-2014, 2014.

Dubovik, O. and King, M. D.: A flexible inversion algorithm for retrieval of aerosol optical properties from Sun and sky radiance measurements, J. Geophys. Res., 105, 20673-20696, doi:10.1029/2000JD900282, 2000.

Dubovik, O., Holben, B., Eck, T. F., Smirnov, A., Kaufman, Y. J., King, M. D., Tanré, D., and Slutskerand, I.: Variability of Absorption and Optical Properties of Key Aerosol Types Observed in Worldwide Locations, J. Atmos. Sci., 59, 3, 590-608, doi:10.1175/1520-0469(2002)059<0590:VOAAOP>2.0.CO;2, 2002.

Gasteiger, J., Groß, S., Freudenthaler, V., and Wiegner, M.: Volcanic ash from Iceland over Munich: mass concentration retrieved from ground-based remote sensing measurements, Atmos. Chem. Phys., 11, 2209-2223, doi:10.5194/acp-11-22092011, 2011.

Gislason, S. R., Hassenkam, T., Nedel, S., Bovet, N., Eiriksdottir, E. S., Alfredsson, H. A., Hem, C. P., Balogh, Z. I., Dideriksen, K., Oskarsson, N., Sigfusson, B., Larsen, G., and Stipp, S. L. S.: Characterization of Eyjafjallajökull volcanic ash particles and a protocol for rapid risk assessment, P. Natl. Acad. Sci. USA, 108, 7307-7312, doi:10.1073/pnas.1015053108, 2011.

Gudmundsson, M. T., Pedersen, R., Vogfjörd, K., Thorbjarnardóttir, B., Jakobsdóttir, S., and Roberts, M. J.: Eruptions of Eyjafjallajökull volcano, Iceland, EOS T. Am. Geophys. Un., 91, 190191, doi:10.1029/2010EO210002, 2010.

Hand, J. L. and Malm, W. C.: Review of aerosol mass scattering efficiencies from ground based-measurements since 1990, J. Geophys. Res., 112, D16203, doi:10.1029/2007JD008484, 2007.

Hansen, J., Sato, M., and Ruedy, R.: Radiative forcing and climate response, J. Geophys. Res., 102, 6831-6864, doi:10.1029/96JD03436, 1997.

Hunton, D. E., Viggiano, A. A, Miller, T. M, Ballenthin, J. O., Reeves, J. M, Wilson, J. C., Lee, S. H., Anderson, B. E., Brune, W. H., Harder, H., Simpas, J. B., and Oskarsson, N.: In-situ aircraft observations of the 2000 Mt. Hekla volcanic cloud: Composition and chemical evolution in the Arctic lower stratosphere, J. Volcanol. Geoth. Res., 145, 23-34 doi:10.1016/j.jvolgeores.2005.01.005, 2005.

Ilyinskaya, E., Tsanev, V. I., Martin, R. S., Oppenheimer, C., Le Blond, J., Sawyer, G. M., and Gudmundsson, M. T.: Near-source observations of aerosol size distributions in the eruptive plumes from Eyjafjallajökull volcano, March-April 2010, Atmos. Environ., 45, 3210-3216, doi:10.1016/j.atmosenv.2011.03.017, 2011.

Jacobson, M. Z.: Strong radiative heating due to the mixing state of black carbon in atmospheric aerosols, Nature, 409, 695697,doi:10.1038/35055518, 2001.

Kandler, K., Schütz, L., Deutscher, C., Ebert, M., Hofmann, H., Jäckel, S., Jaenicke, R., Knippertz, P., Lieke, K., Massling, A., Petzold, A., Schladitz, A., Weinzierl, B., Wiedensohler, A., Zorn, S., and Weinbruch, S.: Size distribution, mass concentration, chemical and mineralogical composition and derived optical parameters of the boundary layer aerosol at Tinfou, Morocco, during SAMUM 2006, Tellus B, 61, 32-50, doi:10.1111/j.16000889.2008.00385.x, 2009. 
Kirchstetter, T. W., Novakov, T., and Hobbs, P. V.: Evidence that the spectral dependence of light absorption by aerosols is affected by organic carbon, J. Geophys. Res., 109, D21208, doi:10.1029/2004JD004999, 2004.

Krotkov, N. A., Bhartia, P. K., Herman, J. R., Fioletov, V., and Kerr, J.: Satellite estimation of spectral surface UV irradiance in the presence of tropospheric aerosols: 1. Cloud-free case, J. Geophys. Res., 103, 8779-8793, doi:10.1029/98JD00233, 1998.

Krotkov, N. A., Flittner, D. E., Krueger, A. J., Kostinski, A., Riley, C., Rose, W., and Torres, O.: Effect of particle nonsphericity on satellite monitoring of drifting volcanic ash clouds, J. Quant. Spectrosc. Ra., 63, 613-630, doi:10.1016/S00224073(99)00041-2, 1999.

Langmann, B., Folch, A., Hensch, M., and Matthias, V.: Volcanic ash over Europe during the eruption of Eyjafjallajökull on Iceland, April-May 2010, Atmos. Environ., 48, 1-8, doi:10.1016/j.atmosenv.2011.03.054, 2012.

Lenoble, J., Mishchenko, M. I., and Herman, M.: Absorption and scattering by molecules and particles, Aerosol Remote Sensing, Springer, Berlin Heidelberg, 13-51, doi:10.1007/978-3-64217725-5_2, 2013.

Lim, S. S., Vos, T., Flaxman, A. D., Danaei, G., Shibuya, K., AdairRohani, H., Amann, M, Anderson, H. R., Andrews, K. G., Aryee, M., Atkinson, C., Bacchus, L. J., Bahalim, A. N., Balakrishnan, K., Balmes, J., Barker-Collo, S., Baxter, A., Bell, M. L., Blore, J. D., Blyth, F., Bonner, C., Borges, G., Bourne, R., Boussinesq, M., Brauer, M., Brooks, P., Bruce, N. G., Brunekreef, B., BryanHancock, C., Bucello, C., Buchbinder, R., Bull, F., Burnett, R. T., Byers, T. E., Calabria, B., Carapetis, J., Carnahan, E., Chafe, Z., Charlson, F., Chen, H., Chen, J. S., Cheng, A. T.-A., Child, J. C., Cohen, A., Colson, K. E., Cowie, B. C., Darby, S., Darling, S., Davis, A., Degenhardt, L., Dentener, F., Des Jarlais, D. C., Devries, K., Dherani, M., Ding, E. L., Dorsey, E. R., Driscoll, T., Edmond, K., Ali, S. E., Engell, R. E., Erwin, P. J., Fahimi, S., Falder, G., Farzadfar, F., Ferrari, A., Finucane, M. M., Flaxman, S., Fowkes, F. G. R., Freedman, G., Freeman, M. K., Gakidou, E., Ghosh, S., Giovannucci, E., Gmel, G., Graham, K., Grainger, R., Grant, B., Gunnell, D., Gutierrez, H. R., Hall, W., Hoek, H. W., Hogan, A., Hosgood III, H. D., Hoy, D., Hu, H., Hubbell, B. J., Hutchings, S. J., Ibeanusi, S. E., Jacklyn, G. L., Jasrasaria, R., Jonas, J. B., Kan, H., Kanis, J. A., Kassebaum, N., Kawakami, N., Khang, Y.-H., Khatibzadeh, S., Khoo, J.-P., Kok, C., Laden, F., Lalloo, R., Lan, Q., Lathlean, T., Leasher, J. L., Leigh, J., Li, Y., Lin, J. K., Lipshultz, S. E., London, S., Lozano, R., Lu, Y., Mak, J., Malekzadeh, R., Mallinger, L., Marcenes,W., March, L., Marks, R., Martin, R., McGale, P., McGrath, J., Mehta, S., Mensah, G. A., Merriman, T. R., Micha, R., Michaud, C., Mishra, V., Hanafiah, K. M., Mokdad, A. A., Morawska, L., Mozaffarian, D., Murphy, T., Naghavi, M., Neal, B., Nelson, P. K., Nolla, J. M., Norman, R., Olives, C., Omer, S. B., Orchard, J., Osborne, R., Ostro, B., Page, A., Pandey, K. D., Parry, C. D. H., Passmore, E., Patra, J., Pearce, N., Pelizzari, P. M., Petzold, M., Phillips, M. R., Pope, D., Pope III, C. A., Powles, J., Rao, M., Razavi, H., Rehfuess, E. A., Rehm, J. T., Ritz, B., Rivara, F. P., Roberts, T., Robinson, C., Rodriguez-Portales, J. A., Romieu, I., Room, R., Rosenfeld, L. C., Roy, A., Rushton, L., Salomon, J. A., Sampson, U., Sanchez-Riera, L., Sanman, E., Sapkota, A., Seedat, S., Shi, P., Shield, K., Shivakoti, R., Singh, G. M., Sleet, D. A., Smith, E., Smith, K. R., Stapelberg, N. J. C., Steenland, K., Stöckl, H.,
Stovner, L. J., Straif, K., Straney, L., Thurston, G. D., Tran, J. H., Van Dingenen, R., Van Donkelaar, A., Veerman, J. L., Vijayakumar, L., Weintraub, R., Weissman, M. M., White, R. A., Whiteford, H., Wiersma, S. T., Wilkinson, J. D., Williams, H. C., Williams, W., Wilson, N., Woolf, A. D., Yip, P., Zielinski, J. M., Lopez, A. D., Murray, C. J. L., and Ezzati, M.: A comparative risk assessment of burden of disease and injury attributable to 67 risk factors and risk factor clusters in 21 regions, 19902010: a systematic analysis for the Global Burden of Disease Study 2010, The Lancet, 380, 2224-2260, doi:10.1016/S01406736(12)61766-8, 2012.

Lohmann, U. and Feichter, J.: Global indirect aerosol effects: a review, Atmos. Chem. Phys., 5, 715-737, doi:10.5194/acp-5-7152005, 2005.

Malm, W. C., Schichtel, B. A., Pitchford, M. L., Ashbaugh, L. L., and Eldred, R. A.: Spatial and monthly trends in speciated fine particle concentration in the United States, J. Geophys. Res.Atmos., 109, D03306, doi:10.1029/2003JD003739, 2004.

Martins, J. V., Artaxo, P., Kaufman, Y. J., Castanho, A. D., and Remer, L.: Spectral absorption properties of aerosol particles from 350-2500 nm, Geophys. Res. Lett., 36, L13810, doi:10.1029/2009GL037435, 2009.

Mishchenko, M. I., Travis, L. D., and Mackowski, D. W.: T-matrix computations of light scattering by nonspherical particles: a review, J. Quant. Spectrosc. Ra., 55, 535-575, doi:10.1016/00224073(96)00002-7, 1996.

Mishchenko, M. I. and Travis, L. D.: Capabilities and limitations of a current FORTRAN implementation of the T-matrix method for randomly oriented, rotationally symmetric scatterers, J. Quant. Spectrosc. Ra., 60, 309-324, doi:10.1016/S00224073(98)00008-9, 1998.

Moosmüller, H., Chakrabarty, R. K., Ehlers, K. M., and Arnott, W. P.: Absorption Ångström coefficient, brown carbon, and aerosols: basic concepts, bulk matter, and spherical particles, Atmos. Chem. Phys., 11, 1217-1225, doi:10.5194/acp-11-12172011, 2011.

Newman, S. M., Clarisse, L., Hurtmans, D., Marenco, F., Johnson, B., Turnbull, K., Havemann, S., Baran, A. J., O'Sullivan, D., and Haywood, J.: A case of study of observations of volcanic ash from the Eyjafjallajökull eruption: 2. Airbone and satellite radiative measurements, J. Geophys. Res., 117, D00U13, doi:10.1029/2011JD016780, 2012.

Patterson, E. M.: Optical properties of the crustal aerosol: Relation to chemical and physical characteristics, J. Geophys. Res., 86, 3236-3246, doi:10.1029/JC086iC04p03236, 1981.

Patterson, E. M., Pollard, C. O., and Galindo, I.: Optical propertiesof the ash from El Chichon volcano, Geophys. Res. Lett., 10, 317-320, doi:10.1029/GL010i004p00317, 1983.

Petzold, A., Rasp, K., Weinzierl, B., Esselborn, M., Hamburger, T., Dörnbrack, A., Kandler, K., Schütz, L., Knippertz, P., Fiebig, M., and Virkkula, A.: Saharan dust absorption and refractive index from aircraft-based observations during SAMUM 2006, Tellus B, 61, 118-130, doi:10.1111/j.1600-0889.2008.00383.x, 2009.

Petzold, A., Veira, A., Mund, S., Esselborn, M., Kiemle, C., Weinzierl, B., Hamburger, T., Ehret, G., Lieke, K., and Kandler, K.: Mixing of mineral dust with urban pollution aerosol over Dakar (Senegal): impact on dust physico-chemical and radiative properties, Tellus B, 63, 619-634, doi:10.1111/j.16000889.2011.00547.x, 2011. 
Pollack, J. B., Toon, O. B., and Khare, B. N.: Optical properties of some terrestrial rocks and glasses, Icarus, 19, 372-389, doi:10.1016/0019-1035(73)90115-2, 1973.

Ramanathan, V. and Carmichael, G.: Global and regional climate changes due to black carbon, Nat. Geosci., 1, 221-227, doi:10.1038/ngeo156, 2008.

Rauthe-Schöch, A., Weigelt, A., Hermann, M., Martinsson, B. G., Baker, A. K., Heue, K.-P., Brenninkmeijer, C. A. M., Zahn, A., Scharffe, D., Eckhardt, S., Stohl, A., and van Velthoven, P. F. J.: CARIBIC aircraft measurements of Eyjafjallajökull volcanic clouds in April/May 2010, Atmos. Chem. Phys., 12, 879-902, doi:10.5194/acp-12-879-2012, 2012.

Reid, J. S., Hobbs, P. V., Liousse, C., Martins, J. V., Weiss, R. E., and Eck, T. F.: Comparisons of techniques for measuring shortwave absorption and black carbon content of aerosols from biomass burning in Brazil, J. Geophys. Res., 103, 32031-32040, doi:10.1029/98JD00773, 1998.

Schulz, M., Textor, C., Kinne, S., Balkanski, Y., Bauer, S., Berntsen, T., Berglen, T., Boucher, O., Dentener, F., Guibert, S., Isaksen, I. S. A., Iversen, T., Koch, D., Kirkevåg, A., Liu, X., Montanaro, V., Myhre, G., Penner, J. E., Pitari, G., Reddy, S., Seland, Ø., Stier, P., and Takemura, T.: Radiative forcing by aerosols as derived from the AeroCom present-day and pre-industrial simulations, Atmos. Chem. Phys., 6, 5225-5246, doi:10.5194/acp-6-5225-2006, 2006.

Schumann, U., Weinzierl, B., Reitebuch, O., Schlager, H., Minikin, A., Forster, C., Baumann, R., Sailer, T., Graf, K., Mannstein, H., Voigt, C., Rahm, S., Simmet, R., Scheibe, M., Lichtenstern, M., Stock, P., Rüba, H., Schäuble, D., Tafferner, A., Rautenhaus, M., Gerz, T., Ziereis, H., Krautstrunk, M., Mallaun, C., Gayet, J.-F., Lieke, K., Kandler, K., Ebert, M., Weinbruch, S., Stohl, A., Gasteiger, J., Groß, S., Freudenthaler, V., Wiegner, M., Ansmann, A., Tesche, M., Olafsson, H., and Sturm, K.: Airborne observations of the Eyjafjalla volcano ash cloud over Europe during air space closure in April and May 2010, Atmos. Chem. Phys., 11, 2245-2279, doi:10.5194/acp-112245-2011, 2011.

Seinfeld, J. H. and Pandis, S. N.: Atmospheric Chemistry and Physics: from Air Pollution to Climate Change, WileyInterscience, USA, 1998.
Shipley, S. and Sarna-Wojcicki, A. M.: Distribution, thickness, and mass of late Pleistocene and Holocene tephra from major volcanoes in the northwestern United States: a preliminary assessment of hazards from volcanic ejecta to nuclear reactors in the Pacific Northwest, US Geological Survey Miscellaneous Field Studies Map MF-1435, 1982.

Twomey, S.: The influence of pollution on the shortwave albedo of clouds, J. Atmos. Sci., 34, 1149-1152, doi:10.1175/15200469(1977)034<1149:TIOPOT>2.0.CO;2, 1977.

Veghte, D. P and Freedman, M. A.: Facile Method for Determining the Aspect Ratios of Mineral Dust Aerosol by Electron Microscopy, Aerosol Sci. Tech., 48, 715-724, doi:10.1080/02786826.2014.920484, 2014.

Volten, H., Muñoz, O., Rol, E., de Haan, J. F., Vassen, W., Hovenier, J. W., Muinonen, K., and Nousiainen, T.: Scattering matrices of mineral aerosol particles at $441.6 \mathrm{~nm}$ and $632.8 \mathrm{~nm}$, J. Geophys. Res., 106, 17375-17401, doi:10.1029/2001JD900068, 2001.

Weinzierl, B., Sauer, D., Minikin, A., Reitebuch, O., Dahlkötter, F., Mayer, B., Emde, C., Tegen, I., Gasteiger, J., Petzold, A., Veira, A., Kueppers, U., and Schumann, U.: On the visibility of airborne volcanic ash and mineral dust from the pilot's perspective in flight, Phys. Chem. Earth, 45-46, 87-102, doi:10.1016/j.pce.2012.04.003, 2012.

Yi, B., Hsu, C. N., Yang, P., and Tsay, S.-H.: Radiative transfer simulation of dust-like aerosols: uncertainties from particle shape and refractive index, J. Aerosol Sci., 42, 631-644, doi:10.1016/j.jaerosci.2011.06.008, 2011.

Yu, H., Kaufman, Y. J., Chin, M., Feingold, G., Remer, L. A., Anderson, T. L., Balkanski, Y., Bellouin, N., Boucher, O., Christopher, S., DeCola, P., Kahn, R., Koch, D., Loeb, N., Reddy, M. S., Schulz, M., Takemura, T., and Zhou, M.: A review of measurement-based assessments of the aerosol direct radiative effect and forcing, Atmos. Chem. Phys., 6, 613-666, doi:10.5194/acp-6-613-2006, 2006.

Yuan, T., Remer, L. A., Bian, H., Ziemke, J. R., Albrecht, R., Pickering, K. E., Oreopoulos, L., Goodman, S. J., Yu, H., and Allen, D. J.: Aerosol indirect effect on tropospheric ozone via lightning, J. Geophys. Res., 117, D18213, doi:10.1029/2012JD017723, 2012. 